\title{
Classification of cultural heritage assets and seismic damage variables for the identification of performance levels
}

\author{
S. Lagomarsino ${ }^{1}$, N. Abbas ${ }^{1}$, C. Calderini ${ }^{1}$, S. Cattari ${ }^{1}$, M. Rossi ${ }^{1}$, \\ R. Ginanni Corradini ${ }^{2}$, G. Marghella ${ }^{2}$, F. Mattolin ${ }^{2}$ \& V. Piovanello ${ }^{2}$ \\ ${ }^{I}$ Dept. of Civil, Environmental and Architectural Engineering, \\ University of Genoa, Italy \\ ${ }^{2}$ Il Cenacolo s.r.l., Italy
}

\begin{abstract}
The paper presents the damage and typological classification for the cultural heritage asset proposed in the PERPETUATE Project funded by the Seventh Framework Programme - Theme ENV.2009.3.2.1.1. The driving ideas of the project are: i) adoption of a performance-based approach for the evaluation of seismic safety of cultural heritage assets and the design of strengthening interventions; ii) identification of proper safety levels considering both conservation and safety issues; iii) minimization of strengthening interventions through increasing knowledge and improving modelling tools. Performance Based Assessment methodology is based on the fulfilment of some target performance levels in correspondence to predefined seismic actions. It generally uses pushover analysis and verification by the capacity spectrum method. In order to define reliable models for pushover analysis and criteria for the performance levels, a classification of both architectonic and artistic assets is proposed in the paper, by considering the corresponding seismic damage modes. On the one hand, such classification allows us to identify the more reliable mechanical models to be used in the description of the seismic response of the different types of buildings and artistic assets; on the other hand, it allows us to define reliable damage variables related to each type of building and main elements of the construction.
\end{abstract}

Keywords: cultural heritage assets classification, performance based assessment, seismic damage modes, masonry buildings. 


\section{Introduction}

The earthquake protection of cultural heritage assets can be realized through a preventive knowledge of the seismic risk, in order to plan mitigation strategies and schedule the necessary strengthening interventions, for the reduction of the vulnerability.

A methodology for evaluation and mitigation of seismic risk to cultural heritage assets is proposed in the PERPETUATE Project (www.perpetuate.eu) funded by the Seventh Framework Programme - Theme ENV.2009.3.2.1.1 and developed by a consortium which includes 5 European Countries (Italy, France, Greece, UK, Slovenia) and 1 International Cooperation Partner Country (Algeria) composed by 6 Universities, 2 Public Institutions and 3 SMEs.

Final aim of PERPETUATE is the development of European Guidelines for the achievement of an homogenous and reasonable low seismic risk to cultural heritage in European and Mediterranean countries. In particular, the Italian "Guidelines for the evaluation and mitigation of seismic risk to cultural heritage" [1] will be the framework for the drawing up of this document. Focusing the attention on masonry structures, the project will face the problem for both architectonic assets (historic buildings or parts of them) and artistic assets (frescos, stucco-works, statues, pinnacles, etc...). The methodology adopted to evaluate the seismic response of an architectonic asset and the contained artistic asset is based on Performance Based Assessment (PBA) [2-4], that is the fulfilment of some target performance levels (limit states linked to the functionality and the cultural properties of the buildings) in correspondence to predefined seismic actions.

PBA generally uses the pushover analysis and the verification by the capacity spectrum method. Building damage levels may be defined from the structural behaviour, by considering both the local and global scale. By considering not only the structural damage but also the response of non structural elements and artistic assets, performance levels may be linked not only to functionality concepts but also to cultural properties of the buildings. To this aim, a multicriteria approach is proposed for the definition of performance levels on the capacity curve, by considering damage at the scale of structural element (local damage), mechanisms in architectonic elements (macroelement), global behaviour (pushover curve). In particular, in the paper, a classification of both architectonic and artistic assets, also considering the relative damage modes, is proposed in order to define the more reliable mechanical models that describe the seismic response of the different types of buildings and artistic assets and that should be used in the pushover analysis. On the basis of this classification, different reliable damage variables could be identified. These variables that are related to each type of building and to main elements of the construction are functional to define the spectral displacements, representative of each damage level on the capacity curve. 


\section{Criteria adopted for the classification}

The modern seismic codes for the design of new buildings, as well as the most advanced recommendations for the evaluation and rehabilitation of the existing ones ([2, 4]), are based on the PBA which uses pushover analysis and verification by the capacity spectrum method. The pushover curve, obtained by performing a non linear static incremental analysis, represents the progressing of non linear response of the structure. In particular usually reference is made to four damage levels: 1) slight damage, 2) moderate damage, 3) heavy damage, 4) severe damage. So starting from damage occurred at different scales, performance levels may be defined in relation to different performance targets of the construction. In particular in PERPETUATE project, different target performance levels are considered for a cultural heritage asset, taking into consideration: use and safety, building conservation and artistic assets conservation, if they are present. Figure 1 illustrates the achievement of target performance levels (that is limit states associated to different displacement levels on the capacity curve) taking into account all the aspects previously introduced.

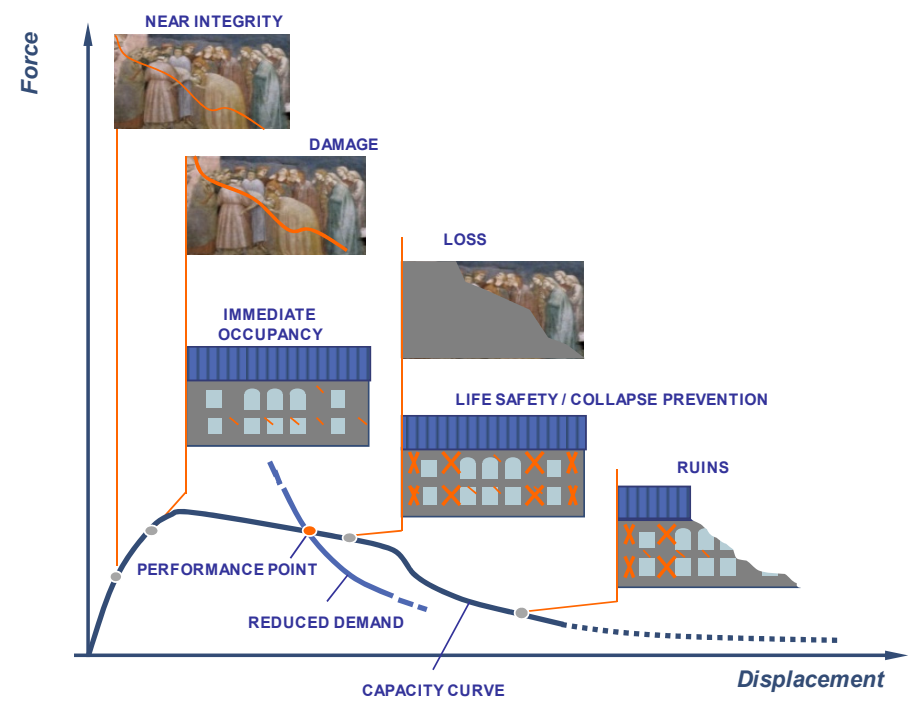

Figure 1: A typical architectonic asset pushover curve with identification of damage and target performance levels.

Damage levels may be defined by considering different scales: structural element scale (local damage); macroelement scale (mechanism in architectonic elements); global scale (pushover curve). At structural element scale, the building damage level can be defined considering the severity and diffusion of damage level in each structural element that is characterized by a non linear behaviour and can be associated to well defined displacement, rotation or deformation (depending on the type of structural element and building type). At 
macroelement scale, the building damage level must take into account the attainment of local damage or collapse mechanisms, even if these are not evident in the global response described by the capacity curve. At global scale, the building damage level can be defined considering the capacity curve of the equivalent non linear single degree of freedom system (representing the global behaviour) by an heuristic approach (i.e.: damage level 1 when the force is $70 \%$ of the maximum strength; damage 2 when building reach the maximum strength; damage 3 when due to softening the force decreases of $20 \%$ with respect to the maximum strength;..). Hence, for the definition of each damage level it is necessary to consider a multi-criteria approach, taking into consideration on a probabilistic base or through a logic tree model all the above mentioned scales.

In order to adopt reliable modelling strategies to perform pushover analyses and identity proper limit states on the capacity curve, firstly a classification of both architectonic and artistic assets must be defined by considering the prevailing seismic damage modes they may be subjected to. To this aim, the classification proposed in the paper may be considered as strictly "mechanical", since the occurrence of different types of damage are closely related to building morphology (architectural form, proportions) and technology (type of masonry, nature of horizontal diaphragms, effectiveness of wall-to-wall and floor-to-walls connections).

As regard the criteria adopted for architectonic assets classification, it is important noting that among the different scale that of "macroelement" has been chosen as the most suitable one to classify the most recurrent seismic behaviour. To better understand this choice it seems important to agree on the meaning attributed to the word "macroelement". The use of "macroelement" word refers to portions of an architectonic asset for which, as testified by the earthquake damage survey, it is possible to recognize recurring seismic behaviour. A macroelement may include a set of structural elements (as in the case of a wall, in which piers and spandrels are included) or, in some cases, may coincide with the structure itself (as in the case of a tower). In general damage to macroelement scale usually leads to a significant load bearing loss of the whole architectonic asset and compromises its functionality. Of course it is evident that the damage assessment at macroelement scale should start from that at element scale and cannot considered independent.

Another important consideration is that this classification should be not intended in a strict way because of complexity of buildings and variety of related macroelements. It is clear that each class and related sub-class collect a wide variety of buildings and single buildings may belong to different classes depending on their specific features (e.g. even if two buildings have the same function they may differ for the morphology or for the constructive and technological details/solutions adopted in different countries they belong to). In this sense it is important pointing out that it is the prevailing seismic behaviour and not, as an example, the use which play the fundamental role in the assignment of a certain class.

As regard the artistic assets classification, focusing the attention only the unmovable artistic assets, two are the main criteria adopted. 
The first one concerns the role, if structural or not, of the asset. The second one is related to the interaction with the architectonic asset which they are linked to (in some cases they are strictly connected to structural elements, in others they show an own independent seismic response).
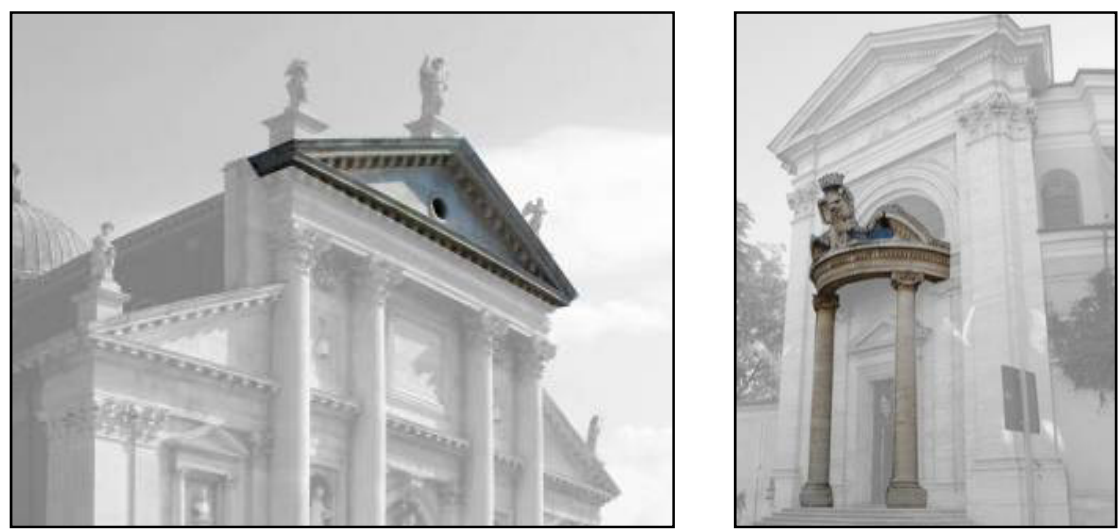

Figure 2: $\quad$ Example of some macroelements for class B1 (churches).
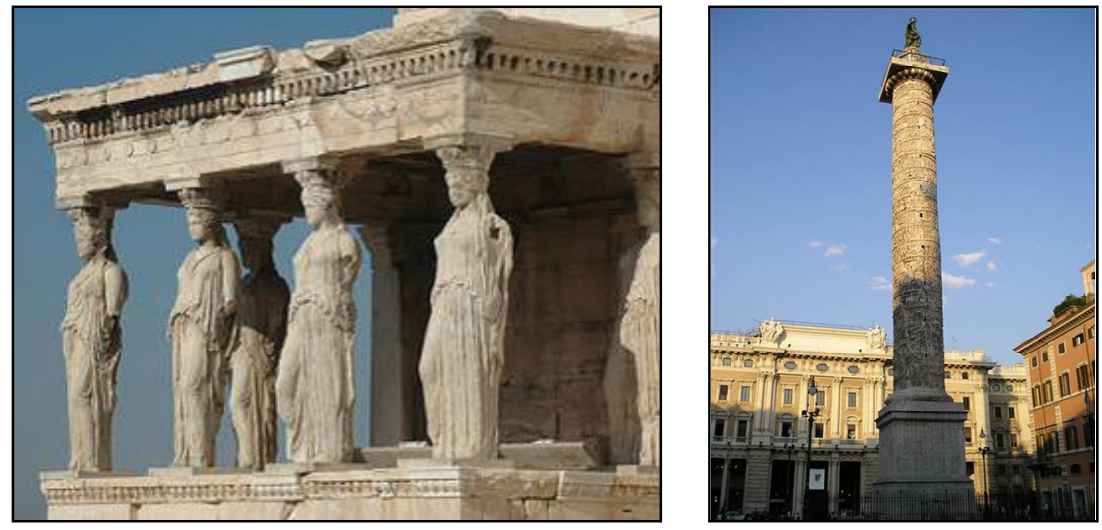

Figure 3: Carved columns which are structural elements themselves (P1) and a column with own seismic behaviour (R1) (in table 3).

\section{Classification of architectonic assets}

The typological classification of architectonic assets is illustrated in this paragraph, starting from the corresponding seismic damage classification.

Concerning the identification of typical damage, the proposed damage classification identifies the most common seismic damage modes which may occur starting from data provided by earthquake damage survey (based on literature review of experimental campaigns or reports on damage survey and 
direct damage assessment data - with particular reference to the following earthquakes: Umbria and Marche (Italy) 1997, Molise (Italy) 2002, Piemonte (Italy) 2003, Brescia and Salò (Italy) 2004, Abruzzo (Italy) 2009).

As mentioned above, damage assessment could start from different scales which are mutually related and among these, the macroelement scale has been chosen as the most suitable one. Also considering the direction of the seismic load (whether in-plane or out-of-plane), nine damage classes are identified as follow: (A) damage to in-plane loaded walls; (B) damage to out-of-plane loaded walls; (C) damage to monodimensional masonry elements; (D) damage to inplane loaded arches (or vaults); (E) local damage of masonry; (F) rocking of single or multiple blocks; $(\mathrm{G})$ damage to roofs and floors; $(\mathrm{H})$ drift of vaults in their horizontal plane; (I) drift of vaults in their horizontal plane. A more detailed description of the seismic behaviour related to these classes is quoted in table 1 .

Since each basic class may include several damage patterns and cracks morphologies as a function of the macroelement geometry, masonry type, quality of connections, etc., some damage sub-classes have been introduced (Table 1).

Table 1: $\quad$ Damage classes and sub-classes.

\begin{tabular}{|c|c|c|}
\hline $\begin{array}{l}\text { Damage } \\
\text { class }\end{array}$ & Description & Damage sub-class \\
\hline \multirow{4}{*}{ A } & \multirow{4}{*}{$\begin{array}{l}\text { This class mainly collect the in-plane } \\
\text { damage of vertical walls, which } \\
\text { progressively leads to the loss of their } \\
\text { bearing capacity. The most typical failure } \\
\text { modes are a function of the type of } \\
\text { structural elements (typically piers and } \\
\text { spandrels) in which damage is } \\
\text { concentrated. Damage in structural } \\
\text { elements may be ascribable to different } \\
\text { types of cracks/prevailing behaviour: } \\
\text { diagonal cracking, bed joint sliding, } \\
\text { rocking, cracks in constructive joints. }\end{array}$} & A-a: generic cracking \\
\hline & & A-b: cracks in piers \\
\hline & & A-c: cracks in spandrels \\
\hline & & $\begin{array}{l}\text { A-d: cracks in structural } \\
\text { gaps }\end{array}$ \\
\hline \multirow{2}{*}{ B } & \multirow{2}{*}{$\begin{array}{l}\text { In this class, partial and global } \\
\text { overturning of walls or masonry elements } \\
\text { are collected. Therefore the collapse } \\
\text { occurs due to loss of equilibrium. }\end{array}$} & $\begin{array}{l}\text { B-a: single block } \\
\text { overturning }\end{array}$ \\
\hline & & $\begin{array}{l}\text { B-b: multi-blocks } \\
\text { overturning }\end{array}$ \\
\hline $\mathrm{C}$ & \multicolumn{2}{|c|}{$\begin{array}{l}\text { This class collects macroelements (as an example system of columns or } \\
\text { pillars) or in some case whole architectonic assets (like as the case of } \\
\text { towers, bell-towers) characterized by a prevailing behaviour which may } \\
\text { be interpreted by referring to the beam theory. }\end{array}$} \\
\hline D & \multicolumn{2}{|c|}{$\begin{array}{l}\text { In this class, arch structures loaded in their vertical plane are considered. } \\
\text { Damage usually involves the arch-and-piers system and occurs by means } \\
\text { of tensile cracks which tend to turn the structure into mechanism. }\end{array}$} \\
\hline
\end{tabular}


Table 1: $\quad$ (Continued).

\begin{tabular}{|c|c|c|}
\hline $\begin{array}{c}\text { Damage } \\
\text { class }\end{array}$ & Description & Damage sub-class \\
\hline \multirow{3}{*}{$\mathrm{E}$} & \multirow{3}{*}{$\begin{array}{l}\text { Damage considered in this class is } \\
\text { localized in limited portions of masonry } \\
\text { continuum. Different types of damage are } \\
\text { included: cracks and spalling in massive } \\
\text { masonry structures due to hydrostatic } \\
\text { thrust; detachment of external masonry } \\
\text { leaf in multi-leaf walls, closure of } \\
\text { openings; pounding of masonry due to } \\
\text { floor of roof beams. }\end{array}$} & $\begin{array}{l}\text { E-a: partial collapse of } \\
\text { external leaf of masonry } \\
\text { walls }\end{array}$ \\
\hline & & $\begin{array}{l}\text { E-b: damage to infill walls, } \\
\text { cavities or structural gaps }\end{array}$ \\
\hline & & $\begin{array}{l}\text { E-c: local damage to } \\
\text { masonry due to impact of } \\
\text { structural elements of } \\
\text { floors/roofs or bolts of tie- } \\
\text { rods. }\end{array}$ \\
\hline $\mathrm{F}$ & \multicolumn{2}{|c|}{$\begin{array}{l}\text { In this class, damage to standing out elements is considered. Usually, due } \\
\text { to their dimensions and boundary conditions, such elements are slightly } \\
\text { compressed and tend to behave as single or multiple rocking blocks. }\end{array}$} \\
\hline \multirow{3}{*}{ G } & \multirow[t]{3}{*}{$\begin{array}{l}\text { In this class, damage to connections of } \\
\text { timber beams and wooden structures is } \\
\text { considered. This type of damage tends to } \\
\text { produce failure of roofs and floors. }\end{array}$} & $\begin{array}{l}\text { G-a: damage in } \\
\text { correspondence of supports } \\
\text { of wooden/steel floors and } \\
\text { roofs }\end{array}$ \\
\hline & & $\begin{array}{l}\text { G-b: sliding of reinforced } \\
\text { concrete beams in case of } \\
\text { r.c. slab }\end{array}$ \\
\hline & & $\begin{array}{l}\text { G-c: damage to structural } \\
\text { elements }\end{array}$ \\
\hline $\mathrm{H}$ & \multicolumn{2}{|c|}{$\begin{array}{l}\text { Damage to vaults subjected to in-plane movements of their abutments are } \\
\text { considered. These movements usually produce shear cracking and local } \\
\text { instability of vaults. }\end{array}$} \\
\hline I & \multicolumn{2}{|c|}{$\begin{array}{l}\text { Typical three-dimensional damage is produced on domes due to their } \\
\text { spatial configuration. Shear, out-of-plane and arch behaviours may } \\
\text { coexist, producing complex damage states. }\end{array}$} \\
\hline
\end{tabular}

As regard the definition of architectonic classes, the classification proposed for architectonic assets is based on "mechanical" criteria, starting from the identification of the most relevant macroelements in historic buildings and on the prevailing damage type which they may be subjected to. Seven architectonic asset classes are identified as follow: (A) assets subjected to prevailing in-plane damage; (B) assets subjected to prevailing out-of-plane damage; (C) assets characterized by monodimensional masonry elements; (D) arched structures subject to in-plane damage; (E) massive structures in which local failure of masonry prevails; (F) blocky structures subjected to overturning; (G) built systems subjected to complex damage. As mentioned in $\S 2$, the classes and subclasses should be not considered in a rigid way. An example may clarify this rational: let consider the case of a palace (sub-class A1). Different 
macroelements may characterize a palace: vertical walls, floors and roofs and vaults, etc. However, between these, the most fundamental one are the vertical walls, for which two classes of damage are defined: the in-plane and the out-ofplane damage. Since, for their technical nature, palaces are more often subjected to in-plane damage, they are associated with class A. This does not mean that palaces cannot be subjected to damage to other macroelements (such floors and roofs). And this does not mean that a single palace, due to its own nature (for example due to presence of particularly slender walls), might be included in class $\mathrm{B}$, in which buildings typically subjected to out-of-plane damage to vertical walls are considered. The table 2 shows the correlation between asset classes and their prevalent seismic behaviour (damage classes).

Table 2: Correlation between type of buildings and damage classification.

\begin{tabular}{|c|c|c|c|c|c|c|c|c|c|c|}
\hline \multicolumn{2}{|c|}{ Damage class } & A & B & $\mathrm{C}$ & $\mathrm{D}$ & E & $\mathrm{F}$ & G & $\mathrm{H}$ & I \\
\hline \multirow{5}{*}{ A } & A1-palaces & & & & & & & & & \\
\hline & A2 - castles & & & & & & & & & \\
\hline & A3 - religious houses & & & & & & & & & \\
\hline & A4 - caravansaries & & & & & & & & & \\
\hline & A5 - collective buildings & & & & & & & & & \\
\hline \multirow{8}{*}{ B } & B1 - churches & & & & & & & & & \\
\hline & $\mathrm{B} 2-$ mosques & & & & & & & & & \\
\hline & B3 - baptisteries & & & & & & & & & \\
\hline & B4 - mausoleums & & & & & & & & & \\
\hline & B5 - hammam & & & & & & & & & \\
\hline & B6 - modern theatres & & & & & & & & & \\
\hline & B7 - markets and bazaars & & & & & & & & & \\
\hline & B8 - industrial buildings & & & & & & & & & \\
\hline \multirow{5}{*}{$\mathrm{C}$} & $\mathrm{C} 1$ - towers & & & & & & & & & \\
\hline & $\mathrm{C} 2$ - bell towers & & & & & & & & & \\
\hline & $\mathrm{C} 3$ - minarets & & & & & & & & & \\
\hline & C4 - lighthouses & & & & & & & & & \\
\hline & C5 - chimneys & & & & & & & & & \\
\hline
\end{tabular}


Table 2: $\quad$ (Continued).

\begin{tabular}{|c|c|c|c|c|c|c|c|c|c|c|}
\hline & $\begin{array}{c}\text { Damage class } \\
\text { Architectonic assetctass }\end{array}$ & $\mathrm{A}$ & B & $\mathrm{C}$ & $\mathrm{D}$ & E & $\mathrm{F}$ & G & $\mathrm{H}$ & I \\
\hline & D1 - triumphal arches & & & & & & & & & \\
\hline & D2 - aqueducts & & & & & & & & & \\
\hline$D$ & D3 - bridges & & & & & & & & & \\
\hline & D4 - cloisters & & & & & & & & & \\
\hline & E1-fortresses & & & & & & & & & \\
\hline $\mathrm{F}$ & E2 - defensive city walls & & & & & & & & & \\
\hline & E3 - Roman and Greek theatres & & & & & & & & & \\
\hline & F1 - columns & & & & & & & & & \\
\hline & F2 - trilithes & & & & & & & & & \\
\hline $\mathrm{F}$ & F3-obelisks & & & & & & & & & \\
\hline & F4 - archaeological ruins & & & & & & & & & \\
\hline & F5 - Greek temples & & & & & & & & & \\
\hline $\mathrm{G}$ & Historical centers & & & & & & & & & \\
\hline & Prevailing behaviour & Pos & le $b$ & aviot & & & . & & avio & \\
\hline
\end{tabular}

\section{Classification of artistic assets}

The typological classification of artistic assets is proposed in this paragraph, starting from the corresponding seismic damage classification.

Considering the identification of typical damage, as well as architectonic damage classification, the artistic one is based on the observation of the prevalent seismic damage modes occurred, starting from data provided by earthquake damage survey. The classification concerns only unmovable assets, in particular: i) structural elements with an artistic value owing to decoration (e.g. carved stone columns); ii) non structural artistic elements that are somehow connected to the construction (e.g. frescos, plasters, pinnacles). Three damage classes are identified: $(\mathrm{P})$ damage to artistic assets which are structural elements; Q) damage to artistic assets which are not structural elements themselves but are strictly connected to structural elements; (R) damage to unmovable artistic assets which are not structural element and have own seismic response. These main classes are subdivided further in several sub-classes as function of different damage patterns and cracks morphologies which might occur while varying the type of material, shape, connection to artistic assets-structural elements, etc. The 
pre-seismic conservation condition of the artistic assets is also considered as a possible precursor: in fact, in some cases the seismic damage can be amplified by a previous deteriorated condition of the asset.

Table 3: $\quad$ Damage classes and sub-classes for artistic assets.

\begin{tabular}{|c|l|l|}
\hline $\begin{array}{c}\text { Damage } \\
\text { class }\end{array}$ & \multicolumn{1}{|c|}{ Description } & \multicolumn{1}{|c|}{$\begin{array}{c}\text { Damage } \\
\text { sub-class }\end{array}$} \\
\hline \multirow{2}{*}{$\mathrm{P}$} & $\begin{array}{l}\text { This class collects damage to structural elements } \\
\text { which have an artistic value owing to decoration. } \\
\text { The types of damage that may occur are those } \\
\text { considered in the damage classes of architectonic } \\
\text { assets (from A to I). }\end{array}$ & $\begin{array}{l}\text { See damage classes } \\
\text { of architectonic } \\
\text { assets } \\
\text { (from A to I) }\end{array}$ \\
\hline \multirow{2}{*}{$\mathrm{Q}$} & $\begin{array}{l}\text { This class collect damage to artistic assets which are } \\
\text { not structural elements but whose behaviour is } \\
\text { strictly dependent on the behaviour of the structural } \\
\text { elements they are attached to. The damage here } \\
\text { considered derives from structural damage. }\end{array}$ & $\begin{array}{l}\text { Q-a: detachment } \\
\text { and loss of parts }\end{array}$ \\
\cline { 3 - 4 } & $\begin{array}{l}\text { This class collect damage to artistic assets which are } \\
\text { not structural elements but have their own seismic } \\
\text { response. The damage related depends on the } \\
\text { specific behaviour of the object considered and on } \\
\text { the connections with the supporting structure. }\end{array}$ & $\begin{array}{l}\text { Q-c: irreversible } \\
\text { deformations }\end{array}$ \\
\cline { 3 - 4 } & R-a: dislocations \\
\cline { 3 - 4 } & $\begin{array}{l}\text { R-b: unthreading } \\
\text { or failure of } \\
\text { connection }\end{array}$ \\
\cline { 3 - 4 } & R-c: overturning \\
\hline
\end{tabular}

As regard the definition of artistic assets classes, the classification proposed in this paper represents a challenging task owing to their great variety. In fact, over 250 elements of the Dictionary of Art [5] have been examined in order to trace this classification. The criteria adopted intends to identify classes on the basis of their seismic behaviour, depending on the role of the asset (if structural or not) and on the interaction with the structural elements they are linked to.

After a reduction, the proposed list consists of 63 cultural assets, classified as showed in the following table.

\section{Final remarks}

The classification of cultural heritage assets proposed in the paper represents the preliminary, but fundamental, step to proceed on Performance Based Assessment. In fact, the identification of their most recurrent seismic behaviour is essential to properly choose the most appropriate modelling strategies to be adopted for pushover analyses. Moreover, this damage classification constitutes the basis for the identification of proper damage variables useful to define criteria to express in quantitative terms the limit states which previously have been introduced only in "qualitative" way (related to functional, safety, conservation issues). 
Table 4: $\quad$ Classes and sub-classes of artistic assets.

\begin{tabular}{|c|c|c|c|}
\hline \multicolumn{2}{|c|}{ Class } & Sub-class & Examples \\
\hline \multirow{4}{*}{$\mathrm{P}$} & \multirow{4}{*}{$\begin{array}{l}\text { Artistic assets which } \\
\text { are structural } \\
\text { elements by } \\
\text { themselves }\end{array}$} & $\begin{array}{l}\text { P1 - carved or shaped } \\
\text { vertical structural assets }\end{array}$ & $\begin{array}{l}\text { Caryatid, carved stone } \\
\text { columns, walls with carved } \\
\text { blocks or shaped bricks, ... }\end{array}$ \\
\hline & & $\begin{array}{l}\mathrm{P} 2-\text { carved or decorated } \\
\text { horizontal structural } \\
\text { assets }\end{array}$ & $\begin{array}{l}\text { Carved stone or wooden } \\
\text { lintels, decorated wooden } \\
\text { beams, ... }\end{array}$ \\
\hline & & $\begin{array}{l}\text { P3 - carved structural } \\
\text { arched assets }\end{array}$ & $\begin{array}{l}\text { Carved stone arches, vaults } \\
\text { and domes, etc. }\end{array}$ \\
\hline & & $\begin{array}{l}\text { P4 - carved or decorated } \\
\text { wooden roof }\end{array}$ & Decorated wooden roof, etc. \\
\hline \multirow{3}{*}{ Q } & \multirow{3}{*}{$\begin{array}{l}\text { Artistic assets which } \\
\text { are not structural } \\
\text { elements (strictly } \\
\text { connected to } \\
\text { structural elements) }\end{array}$} & $\begin{array}{l}\text { Q1 - assets connected to } \\
\text { vertical structural } \\
\text { elements }\end{array}$ & $\begin{array}{l}\text { Carved stone plates, frescos, } \\
\text { mosaics, stuccoes, ... }\end{array}$ \\
\hline & & $\begin{array}{l}\text { Q2 - assets connected to } \\
\text { the intrados of horizontal } \\
\text { and arched structural } \\
\text { elements }\end{array}$ & $\begin{array}{l}\text { Frescos, mosaics, stuccoes, } \\
\text { wooden or plaster false } \\
\text { ceiling, light thin plaster } \\
\text { vaults, ... }\end{array}$ \\
\hline & & $\begin{array}{l}\text { Q3 - assets connected to } \\
\text { the extrados of horizontal } \\
\text { structural elements }\end{array}$ & $\begin{array}{l}\text { Floor with mosaics, } \\
\text { decorated tiles, parquets, ... }\end{array}$ \\
\hline \multirow{3}{*}{$\mathrm{R}$} & \multirow{3}{*}{$\begin{array}{l}\text { Artistic assets which } \\
\text { are not structural } \\
\text { elements (with own } \\
\text { seismic response) }\end{array}$} & $\begin{array}{l}\mathrm{R} 1 \text { - assets leant on } \\
\text { horizontal structural } \\
\text { elements }\end{array}$ & $\begin{array}{l}\text { Altars, sculptures, pulpits, } \\
\ldots\end{array}$ \\
\hline & & $\begin{array}{l}\mathrm{c} 2 \text { - assets jutting out } \\
\text { from vertical structural } \\
\text { elements }\end{array}$ & $\begin{array}{l}\text { Balconies, shelves, } \\
\text { gargoyles, ... }\end{array}$ \\
\hline & & $\begin{array}{l}\text { R3 - assets hanging on } \\
\text { horizontal structural } \\
\text { elements }\end{array}$ & Lamps, bells, crosses, ... \\
\hline
\end{tabular}

Usually, these variables are expressed in terms of deformations or displacements; however they have to be differentiated on the basis of the damage classes previously defined and the specific macroelements considered. Concerning architectonic assets, although the scale of observation is the macroelement one, proper damage variables have to be defined also at element scale. As an example, with reference to the class of damage A (Damage to inplane loaded walls), the drift parameter is usually adopted. This is the only damage parameter for which quantitative values are available in the literature; as a function of the limit state considered, some codes $([2,4])$ propose to refer to different drift limit values evaluated both on the interstory height or on the single structural element height (i.e. piers and spandrels). Damage variables for damage class B (for which models based on rigid blocks limit analysis are usually adopted) should be referred to overall displacements, defined on the global capacity curve of the macroelement considered. Since it is very difficult to evaluate by mean of experimental tests the absolute displacements associated to out-of-plane failures (due to the dynamic instability of the phenomenon), 
reference values should be defined as a rate of the displacement leading the macroelement to loss of stability. Concerning artistic assets, in some cases (i.e. for class P) damage variables are the same of architectonic ones; for class Q may be also considered similar (with different parameter values), while different criteria must be defined in the class $\mathrm{R}$. In case of artistic assets, the definition of proper limit values becomes even more difficult due to very limited number of experimental campaigns specifically addressed to this aim.

It is evident how all afore mentioned issues stress the need of further developments to define the complete set of damage variables for all classes which has been defined (to this aim, in PERPETUATE project some specific experimental campaigns have been planned).

\section{Acknowledgements}

The results proposed in the paper have been achieved in the project PERPETUATE (www.perpetuate.eu), funded by the European Commission in the Seventh Framework Programme (FP7/2007-2013), under grant agreement $\mathrm{n}^{\circ}$ 244229 .

\section{References}

[1] Guidelines for evaluation and mitigation of seismic risk to cultural heritage, Directive of the Prime Minister, 12/10/2007, G.U. n.24 of 29/1/2008, Gangemi Editor, Rome, 2007.

[2] FEMA 356. Prestandard and commentary for the seismic rehabilitation of buildings. ATC: Washington, 2000.

[3] Seismic Rehabilitation of Existing Buildings, ASCE Standard ASCE-SEI 41-06, 2007.

[4] Eurocode 8. Design of structures for earthquake resistance. Part 3: Assessment and retrofitting of buildings. ENV 1998-3, CEN: Brussels, 2005.

[5] Myers, S. B., Dictionary of Art, McGraw-Hill, New York-London, 1969 